\title{
Creating Women Concept-Characters in P. Zagrebelny's Fictional Discourse
}

\section{Creación de personajes-conceptos femeninos en el discurso ficticio de $\mathbf{P}$. Zagrebelny}

\section{Nataliia Karpenko}

Ph. D (Philology), Associate Professor, Department of Philology, Translation and Strategic Communication, Humanities Faculty, National Academy of the National Guard of Ukraine.

ORCID: https://orcid.org/0000-0003-2922-0384

\section{Viktoriia Shcherbyna}

Ph. D (Philology), Associate Professor, Department of Philology, Translation and Strategic Communication, Humanities Faculty, National Academy of the National Guard of Ukraine. ORCID: https://orcid.org/0000-0002-2717-3855

\section{Liliia Doroshyna}

Ph. D (Philology), Associate Professor, Department of Philology, Translation and Strategic Communication, Humanities Faculty, National Academy of the National Guard of Ukraine. ORCID: https://orcid.org/0000-0002-0199-4372

Received 06-12-20 Revised 08-25-20

\section{*Correspondence}

Email: ivannovadremova29@gmail.com

\section{Cite as:}

Karpenko, N., Shcherbyna, V., Doroshyna, L. (2021). Creating Women Concept-Characters in P. Zagrebelny's Fictional Discourse. Propósitos y Representaciones, 9 (SPE1), e917. Doi: http://dx.doi.org/10.20511/pyr2021.v9nSPE1.917 


\section{Summary}

The article focuses on the verbalisation of the concept woman in P. Zagrebelnyi's fictional discourse. The artist is analysed, on the one side, as a linguistic personality with his features of psyche, as a representative of a language group, and on the other side, as a creative personality that uniquely represents himself in fictional discourse, creative dimensions with his features of communicative behaviour. The analysis of the concept is performed regarding the achievements of psycholinguistics, gender linguistics, lingua-cultural studies, pragmatically-oriented communicative linguistics, on the basis of anthropocentric and discoursecentric paradigms, that made it possible to identify senses in the structure of the concept and clarify the mechanism of their occurrence. Attention is paid to the writer's fictional discourse, which is analysed with regard to principles of discourse-analysis. Therefore, extralingual factors that gave rise to certain lexemes representing the concept are crucial for the research. As a result of the study, groups of lexemes that constitute the concept and denote animals, birds, natural phenomena, pieces of land were revealed. Nouns that constitute a layer of military vocabulary and name psychological states and contain negative connotations were identified. Features characteristic of women representatives of Ukrainian culture are compared and contrasted with the descriptions of women representatives of other cultures. The language units, evoked by the mentality and mental outlook of Ukrainians, were analysed.

Key words: concept-character, connotation, discourse analysis, extralingual factors, fictional discourse, linguistic personality, military language.

\section{Resumen}

El artículo se centra en la verbalización del concepto mujer en el discurso de ficción de P. Zagrebelnyi. El artista es analizado, por un lado, como personalidad lingüística con sus rasgos de psique, como representante de un grupo lingüístico, y por otro lado, como personalidad creativa que se representa de manera única en el discurso de ficción, dimensiones creativas con su características del comportamiento comunicativo. El análisis del concepto se realiza en torno a los logros de la psicolinguística, la lingüística de género, los estudios lingüístico-culturales, la lingüística comunicativa pragmáticamente orientada, a partir de paradigmas antropocéntricos y discursivos, que permitieron identificar sentidos en la estructura del concepto y aclarar el mecanismo de su aparición. Se presta atención al discurso de ficción del escritor, que se analiza con respecto a los principios del análisis del discurso. Por tanto, los factores extralingüísticos que dieron lugar a ciertos lexemas que representan el concepto son cruciales para la investigación. Como resultado del estudio, se revelaron grupos de lexemas que constituyen el concepto y denotan animales, aves, fenómenos naturales, pedazos de tierra. Se identificaron sustantivos que constituyen una capa de vocabulario militar y nombran estados psicológicos y que contienen connotaciones negativas. Los rasgos característicos de las mujeres representantes de la cultura ucraniana se comparan y contrastan con las descripciones de mujeres representantes de otras culturas. Se analizaron las unidades lingüísticas, evocadas por la mentalidad y la actitud mental de los ucranianos.

Palabras clave: concepto-carácter, connotación, análisis del discurso, factores extralingüísticos, discurso ficticio, personalidad lingüística, lenguaje militar.

\section{Introduction}

Word as a means of material realisation of consciousness correlating with realias and environmental phenomena makes it possible to study cognitive processes of a human owing to verbal means of its representation and the notion of a concept is a 'gateway' to those mental operations. Such view resulted in various cross-disciplinary studies focusing on language, psyche, mentality, consciousness etc., and brought the notion of the concept to the fore.

In this study two main approaches to the study of concept (cognitive and lingua-cultural) are taken into account. According to the cognitive approach (Lakoff, 2014; Langacker, 2009; 
Zhabotynska, 2009), concept is a mental and cognitive unit, according to lingua-cultural approach it is a unit that accumulates and represents cultural information, the mentality and spirit of the nation (Stepanov, 2004; Karasyk and Slyshkin, 2001).

The purpose of the research is to find out the language units comprising concept-character woman in P. Zagrebelny fictional discourse and define extralinguistic factors that brought about lexemes in the concept structure.

Therefore, the objectives are: to select the lexemes that comprise the concept woman in P. Zagrebelny's fictional discourse; to outline extralingual factors that brought about the structure of the concept; to trace the dynamics of the concept and find out the characteristics typical of Ukrainian ethnopsychology; to identify the language units representing the concept that are characteristic of P. Zagrebelny idiostyle.

The relevance of the research results from the necessity to study the linguistic personality of the writer comprehensively, as a representative of Slavic culture and elite personality with regard to tendencies of modern poliparadigmatic linguistics. The importance of the study also lies in the developing the theory of descriptions of concept-characters in fictional discourses by famous writers.

It is accepted that concepts are constituents of human cognition and units that enable recognition of objects around us, processing the information gained through interaction with the world. "Concepts include the sum of our sensory and motor experiences with the environment in a categorial fashion they gained" (Kiefer \& Pulvermüller, 2012, p. 805) with further storage of it in long-term memory. Moreover, it is a medium of cultural information as a human belongs to nature and culture and "if we take away natural part only immaterial one will remain, if cultural part will be removed, the organism will remain. In this respect all concepts which are operated by a human are cultural concepts" (Karasyk, 2002: 28). Therefore, the concept-character has to be considered in terms of its psychological nature and lingua-cultural factors.

\section{Theoretical framework}

Within this study the importance of the work by T. Sukalenko, devoted to metaphoric realization of the concept woman in the Ukrainian language, can't be stressed enough (Sukalenko, 2010). The problem of verbalisation of the gender concept man was studied by A. Arkhangelska, (Arkhangelska, 2007). Means of language representation of the concept woman in English literature were analysed by V. Vasiuk (Vasiuk, 2002), O. Chybysheva (Chybysheva, 2005), the concept in the Russian langage was studied by L. Adonina (Adonina, 2007), M. Alekseenko (Alekseenko, 2007).

Regarding the ontology of the concept-character woman and its verbalisation in a man's language, the study must be carried out taking into account the gender linguistics postulates. Moreover, the notion of "discourse" has to be engaged as the context where the utterance takes place is also taken into consideration.

\section{Methodology}

The methodology of the research is based on the principles of anthropocentrism which predominantly lays the foundation for the studies in the field of linguistics nowadays. Theoretical principles of modern pragmatically-oriented linguistics within functional, lingua-conceptual, lingua-cultural, gender paradigms, projected to the anaysis of the concept, served as a metodological basis of the research.

To solve the undertaken tasks the following methods were used: method of selection was used to find out the lexemes which have the common semes "person", "female" and comprise the concept woman. Descriptive method was used to characterise units representing the concept, 
distributive method was applied for the purpose of finding out newly created lexico-semantic variants in the words representing the concept, with the help of component and conceptual analyses semantic structure of the lexemes was identified, corresponding conceptual senses and axiologial components were established, discourse analysis was engaged for defining social and cultural factors that brought about the features of the concept and its dynamics.

\section{Results and Discussion}

Cognitive linguistics is focused on establishing the mechanisms of thinking processes (Evans and Green, 2006). The discovery of conceptual metaphor, categorising and communicating ideas via language nowadays are accepted in linguistics (Lakoff, 2014) It has mental nature, but at the same time it is a culturally determined unit of individual or collective consciousness and partially expressed in language. The structure of the concept is motivated by the ideology of a particular social group. Therefore, concepts are labial phenomena with a dynamic sense structure. Speaking about concept-character, esthetic nature and figurative means of expression in literary works are brought to the fore.

Discourse study stems from the works by such scholars as G. Brown, J. Grimes, T. van. Dijk, N. Fairclough, G. Jule, W. Chafe etc. Despite the numerous researches devoted to the term later, it hasn't received a single definition. They are varied in terms of aproaches and the fields of study. Discourse is viewed as a dynamic entity that correlates with other discourses and reflects their elements by mixing with them. Here the intertextuality emerges. Each personality is limited in some way by the framework of existing discourses but synthesising and combining the results of social practice, a personal discourse is being built, a personal attitute to the the fragments of reality is being created, "on the one hand, actions are concrete, individual and context-bound; on the other hand, they are institutionalised and socially anchored, and because of this tend towards patterns and regularity" (Jørgensen, 2004, p. 18).

Therefore, discourse is a dynamic process, means of communication, that is created by the interlocutor in a concrete context, it implies conveying the message and achieving some goal, and the task for a linguist, as G. Brown and G. Jule state (1983, p. 28), is to interpret that message. In this study discourse is viewed as "a coherent text with extralingual factors, which are pragmatic, socio-cultural, psychological and others”. (Arutiunova, p. 136).

The aim of discourse-analysis is to identify various lingua-cultural factors which influence human interaction and creating different discourses. The material for discourse-analysis can be any fragment of speech represented by a concrete genre. In the article fragment of P. Zagrebelny's fictional discourse ("Roksolana", "Yevpraksiia", "Yuliia or invitation to suicide" novels) is analysed.

P. Zagrebelny's language as the language of an elite personality (Karpenko, 2010) is a valuable sourse for researches that represents the abundance of expressive means of the Ukrainian language, the uniqueness of the writer's thinking that results in the range of individual associations. It should be noted that, "individual concepts are richer and more various than any collective one, from microgroup to those common to all mankind, as collective consciousness and collective experience are nothing but relative derivate from consciousness and experience of individuals that constitute a community" (Karasyk, Slyshkin, 2001, p. 75).

A range of associations that demonstrate branching of assotiative and verbal connections in the writer's linguistic consciousness, is revealed in P. Zagrebelny's fictional language. Names of birds are commonly used in the novels, for example, ornithonym turtle dove which is used to denote emotional state of grief and solitude: As a turtle dove in a dry tree (Zagrebelny, 2004, p. 48). For the Ukrainians turtle dove is an embodyment of loyalty as the birds don't fly on their own and in case of losing a mate they grief for it and sit only on dry branches (Zhaivoronok, 2006, p. 145-146). 
To describe an emotional state of a woman that is the result of loosing her children the writer uses a simile: as an owl on ruins, as a lonely bird (Zagrebelny, 2004, p. 522). An owl as an ambivalent symbol embodies, on the one side, wisdom, on the other, danger and misfortune (Zhaivoronok, 2006, p. 558), that motivated corresponding negative associations. Ornithonym $a$ bird and its derivatives (пташеня, пташка, пташина) are frequent in the writer's speech. The distribution of the nouns indicates the associations that arise to the noun bird with the state of grief as well as with chastity: innocent and holy, as a newly-born birdy (Zagrebelny, 2006, p. 45). Such comparison is typical of the collective consciousness and mentality of the Ukrainians, as well as the comparison дівчина - квітка (a girl-a flower): chaste as a morning flower, washed in dew (Zagrebelny, p. 2006: 29).

Such mental aspirations of Ukrainians as love of freedom and fighting for independence result in verbal connections with the zoonyms fallow-deer, fish, animal: ... was fighting, struggling, breaking loose as a fish in a net, as a bird, in woodlands, as a fallow-deer in coarse hands (Zagrebelny, 2004, p. 311). Distribution of the lexemes proves the actualisation of caracteristics typical of animals which fell victims to humans while hunting and tried to free themselves.

A separate group comprises zoonyms with negative axiological charge which is proved by their distribution. They were brought about by the P. Zagrebelny's biography as the writes took part in military operations in the times of World World II. Lexemes breeding pig (свиноматка), female (самиия), female cow (телиия), таrе (кобила) were used to describe women who are representatives of different cultures and were the result of metaphoric rethinking on the base of actualisation of negative associations with the looks of the animals, their weight and awkwardness: fat-bottomed German mare (Zagrebelny, 2004, p. 100), big and stupid female cow (Zagrebelny, 2006, p. 327); SS breeding big (Zagrebelny, 2004: 76); well-fed German female cows (Zagrebelny, 2004, p. 77). The writer uses generic nomination самиця in its lexico-semantic variant 'a woman as a bearer of women's sex features; loose, voluptuous woman' (Dictionary of Ukrainian language, 1970-1980, IX, p. 27): large females (Zagrebelny, 2006, p. 326). At the same time lexeme mare represents the semes 'stubbornness', 'disobedience', 'wildness' and is used to denote a Ukrainian woman. The usage of the noun is motivated by the desire of freedom and liberty: headstrong Russian mare (Zagrebelny, 2004, p. 144).

Negatively marked nouns focus attention on the perception of a German woman as an enemy, alien person who practices witchcraft, that is represented by the corresponding nouns: Enemy. She-wolf. German witch (Zagrebelny, 2004, p. 72). In this context the gradation is developed for the intensity of the negative evaluation.

The usage of the feminative tigress (The yard is crowded with widows. As tigresses in cages! (Zagrebelny, 2004, p. 141) shows despair, rage of a widow that are associated with the state of animals that were caged. In this case a complicated figure was created where a metaphor overlaps with metonymy. The mechanism woman - animal - wild beast shew was developed. The thought of T. Sukalenko (Sukalenko, 2010) that comparisons of a woman with a tigress is a distinguishing feature of $\mathrm{P}$. Zagrebelny idiostyle is proven here.

The zoonym otter in the Ukrainian language displays the pragmatics of disregard and points out the looks of the woman: видра (otter) - "a skinny woman" (derogatory) (Dictionary of Ukrainian language, 1970-1980, I, p. 392), but in the writer's discourse zoonym gains a specific semantics: young carelessly dressed otters were pushing lazily (Zagrebelny, 2006, p. 79). Semes that appeared in P. Zagrebelny's discourse don't match the meanings and odalisques are described as fat, full-fed (Zagrebelny, 2006, p. 150). Obviously, the noun видра (otter) highlights the senses that display inner portrait of the woman. For instance, in the Russian language zoonym shows direct negative evaluation - "about unpleasant woman" (Russian.: грымза, крыса, мылмра, мындра, халда, чувырла) (Osipov, 2003, p. 71). 
The writer creates a simile by comparing a girl and a trembling poplar, that was brought about by the characteristics af a tree that trembles and the ability of human organism to display the external signs of experiencing fear: Trembled as a trembling poplar on a windless day (Zagrebelny, 2004, p. 179).

The similes resulting from the comparisons with natural penomena are also used to display the structure of the concept: she was as a wind, that nobody can settle, as a river that nobody can stop, as a land that nobody can walk around (Zagrebelny, 2006: 106). These similes are brought about by their symbolic meanings. This exposes such feature of Ukrainian philosophic worldview as antheism. Wind is a symbol of quickness, drive, madness... symbol of variability and changes" (Vovk, 2006, p. 91), river refers to wildness, changeability, the comparison with land is motivated by the vastness of the suface area that associates with the inability to understand women's actions. Such associations are not the only in the writer's consciousness as the comparisons with the land that arise from desire of a man-warrior to conquer and be the owner of this particular land are also identified: the land for him became as if it was an attractive woman that you want to possess (Zagrebelny, 2004, p. 94).

The usage of the noun island in respect of a woman results from the remoteness of the land and inapproachability of the woman (with reference to Roksolana who kept a distance from the Turkish society), for example: uapproachable, as a rocky island in the midst of rough sea (Zagrebelny, 2006, p. 156). Aspiration for self-understanding, retreat and introvercy are characteristics of the Ukrainian ethnopsychology. Subsequent invasive military campaigns force the wife to be lonely in the face of her problems and doom her to solitude which evokes a simile woman - temple (храм), for example: lonely as a temple (Zagrebelny, 2006, p. 569).

The lightness of a girl evoked the comparison with a cloud: as light as a cloud (Zagrebelny, 2004, p. 50). Associations that are based on the similarity of visual features of a plant and a slim, tall girl brings about the comparisons тростина (thin reed), билинка (blade of grass) та рослина (plant): tall, thin, as if she would break, as a thin reed under the wind (Zagrebelny, 204, p. 334), she bent supply, as a rare plant (Zagrebelny, 2006, p. 486); little and thin, as a girl, as a blade of grass (Zagrebelny, 2006, p. 476), twisting, as green ivy (Zagrebelny, 2006, p. 48). For Ukrainians ivy symbolizes immortality, revival (Kononenko, 2015), accordingly, the simile reflects vitality and woman's energy which she preserves despite unfavourable circumstances.

To represent inner features of the woman P. Zagrebelny uses the comparison промінь (sunray) and соловей (nightingale) (basic symbol of the Ukrainians): tender, as a sunray, vulnerable, as a loving nightingale (Zagrebelny, 2006, p. 509). The Sun is one of the main symbols of universal consciousness that has predominantly positive symbolism and reflects "vitality, divine creative energy, eternal youth and passion" (Vovk, 2006, p. 60).

The usage of military language for the representation of the concept-character woman is determined by a gender factor, topic of the novel and facts from the P. Zagrebelny's biography (participation in World War II). To denote a woman whose favour a man is trying to obtain the noun фортеия (fortress) is used. The features of the building that is protected from attacks of the enemies and characteristics of a woman whose affection is difficult to gain served as the basis for the metaphoric transference: gaining by assault, unassailable fortress named Yuliia (Zagrebelny, 2002, p. 262). Correlation жінка - військо (woman - army) that is motivated by the aspiration for struggle, subjugation and similarity of the feelings, evoked by the victory over the rival and gaining the favour of the woman: She becomes more dangerous than a large army. The army can be defeated - a woman can't (Zagrebelny, 2006, p. 145).

The semantics of the means of verbalisation of the concept-character woman proves not only the subjugation of a woman by a man, but also subjugation of a man by a woman: you are weak and helpless in front of her, and the only thing you are capable of is capitulation 
(Zagrebelny, 2002, p. 21). Using the lexeme capitulation in its lexico-semantic variant "refusal to fight, acceptance of weakness in the face of something or somebody" (Dictionary of Ukrainian language, 1970-1980, VI, p. 95), the writer represents the state of dependence, subjection of a man.

The means of verbalisation of the concept-character that reflect separation of a man from a woman are also found: Tank- soldier can't stay in his tank forever $<\ldots>$ The same is with a woman. She is as a tank for a short battle (Zagrebelny, 2004, p. 50). In the writer's discourse the lexeme танк (tank) generates new senses when combined with the adjective короткий (short) and the noun бiü (battle). Therefore, the noun is used to indicate short-term relationships between a man and a woman.

Chastity as a dominant characteristic of a Ukrainian woman is represented by corresponding senses in adjectives незіпсована, чиста, непорочна, праведна, невинна, свята, неторкана, инотливо-хтива. Such senses, as 'moral chastity', 'saintliness', 'honesty' are identified in the comparison of the girl with чистою сльозою (a pure teardrop) (Zagrebelny, 2004, p. 119). Teardrops for Ukrainians are the symbol of atonement, making satisfaction for sins (Zhaivoronok, 2006, p. 553). The comparisons of a girl and a well (криничею) $(<\ldots>$ hoping, that he would greedily grab the girl, and having drunk from that clear well, would drop her, as he had done before (Zagrebelny, 2004, p. 131) is motivated by collective consciousness of the Ukrainians as for the Ukrainian ancestors a well was a much revered holy symbol (Zhaivoronok, 2006, p. 315-316), the waters in the wells were seen as such that possessed cleanup and healing power. The writer compares a girl with an angel - beautiful as an angel (Zagrebelny 2004, p. 47). The basis for the simile is saintliness of a girl and a heavenly being, but it is based on the looks which an angel has got.

A comparison жінка - иерква (шотаn - church) is also revealed. It brings about semes "moral purity", "saintliness" and "chastity": Only the church remained, within the walls of it the most terrible happened, stained as she, Yevpraksiia, but anyway almighty (Zagrebelny, 2004, p. 170).

A woman's nature is mysterious to a man and sometimes evokes a sense of fear, danger: All the women that were marked by the name Yuliia, actually, weren't women, but were as space, wild, dark, fearful, as Asia (Zagrebelny, 2002, p. 320). The comparison of a woman with Asia was brought about by the correlation of the vastness of the part of the world and the variety of displays of a woman's character, impossibility to understand her actions.

A range of nouns with the semes 'fatality', 'imminence' and with abstract meanings is used for the verbalisation of the concept-character. This fact is the evidence of unreal nature of the referent and fateful destiny of a woman: destiny, fate, happiness (Zagrebelny, 2002, p. 151) bliss (Zagrebelny, 2002, p. 242), southern skies (Zagrebelny, 2002, p. 204). Obviously, the usage of the noun вирій (southern skies) is the result of positive associations evoked by the calmness which is achieved by a man who spends his time with a beloved woman and the place with warm, pleasant weather conditions. In Slavonic pagan myths вирій was sorted with Christian paradise (Shaparova, 2001, p. 197). For the representation of the concept-character the lexeme paradise (віднайдений рай) was used (Zagrebelny, 2002, p. 322). The content of the concept-character is revealed by the abstract nouns with negative semantics and the senses 'emotional disorder', 'inapproachability', 'illusion': delirium, utter madness (Zagrebelny, 2002, p. 256).

A distinctive feature and highlight of the "Yuliia or invitation to suicide" novel are numerous descriptions of a woman's body (Karpenko, 2009), for example.: mysterious, lush, shameless, almighty, powerfull body (Zagrebelny, p. 2002); soft as warm wax, and solid as steel, $<\ldots>$ bitter and sweet, as wild honey (Zagrebelny, 2002: 203): chaste in the light and wildly shameless in the darkness (Zagrebelny, 2002, p. 205). the basis for comparisons is the similarity of tactile and taste senses of perception. Antonymic semes solid - soft, bitter - sweet in the 
structure of the adjectives are observed, that enhances the expressive charge of the utterance. Antonyms chaste - shameless create antithesis in the canvas of the novel.

A simile body-desert is also used for the purpose of expressing physical state of a man that has intensive feelings towards woman: evasive woman body, that burned him, as a red desert <...> (Zagrebelny, 2004, p. 184).

The nucleus of the notion is distingished in the structure of the concept-character which correlates with universal object code and verbalised by the name of the concept жінка (woman). Its meaning is comprised of archetypal senses 'life', 'birth', 'fertility'. The content of circumnuclear zone is socially determined, dynamic and axiologically marked.

Metaphors traditional for Ukrainian folklore (girl - flower, girl - bird) and individual ones created by the writer (woman - church, woman - temple, etc.) are found out among metaphors, explicating corresponding concept-character. It should be noted that P. Zagrebelny tends to express his idiostyle by comparing women with land (island, land, Eurasia, Asia, desert).

\section{Conclusions}

The findings show that components of the concept-character are the reflection of the ethnic and psycological associations of the Ukrainians. As the evidence for that a range of metaphors, similes were distinguished and analysed regarding the postulates of gender linguistics. They reflect the idea of total freedom, independence, that are exposed in the lexemes with the semes 'power', 'victory', 'fight', 'love of freedom', etc. Alongside there's a global tendency to closeness with nature which is manifested through zoosemy. With regard to the postulates of psycholinguistics and linguaculturology they reflect the characteristics of states of mind, feelings and emotions of women, that is a display of cordocentrism as a streak of Ukrainian mentality and a result of complexity of a woman's psyche, acculturation.

As for the dynamics of the concept, the semes 'lust', 'looseness', 'shamelessness' were revealed in "Yuliia or invitation to suicide" novel. It should be noted that chronological borders of the novel are the closest to the modern period. Moreover, the lexemes that describe numerous physical aspects of relationships between a man and a woman were exposed in the novel. This tendency is not observed in the "Yevpraksiia" and "Roksolana" novels. Obviously, the frequency of the descriptions of a woman's body conveys the perseption of a woman through the system of modern values, the change of which brought about new vocabulary. Some women's features and characteristics which were not recommended to write about are getting new evaluation as "the main (positive) feature of a woman is said to be 'sexuality' and 'eroticism' (by the way it is connected to the distortion of the meaning of 'love')" (Lysychenko, 2009, p. 28).

Concept-characters of the Ukrainian women display positive associations in P. Zagrebelny's consciousness. Alternatively, lexemes that constitute concept-characters that convey the mentality of a foreign culture (Turkish, German, Circassian) stand out by negative associations. This tendency is the result of the display of the dichotomy native - alien.

The writer often resorts to comparisons of women with pieces of land, which is characteristic of his idiostyle. Active usage of military language is also typical of him. This results from his participation in World War II.

In all the novels by P. Zagrebelny that were analysed the semes 'mysteriousness', 'unexpectedness', 'unpredictability', 'innocence', 'moral purity', 'chastity' were identified and defined as the ones that arise in the discourse all over again and characterise P. Zagrebelny's idiostyle. 
The perspective of further researches is seen in compiling associative dictionaries, and the dictionary of P. Zagrebelny's language dictionaries where the concept woman will be an important constituent regarding its various and numerous assossiations.

\section{Bibliographic References}

Adonina, L. (2007). Concept «woman in Russian linguistic concsiousness. [Extended abstract of candidate's thesis]. Voronezh.

Alekseenko, M. (2006). Is the image of woman negative in Language? A word in a dictionary and discourse.

Arkhangelska, A. (2007). «Man» in Slavic Languages. Rivne: RIS KSU.

Arutiunova, N. (1999). Language and the world of a human. Moscow: Languages of Russian Culture.

Brown, G., and Yule, G. (1983). Discourse analysis. Cambridge University Press.

Chybysheva, O. (2005). Kontsept «Zhenshchina» v russkoi i angliiskoi fraseologii (na materiale predmetnyh frazeologizmov, imenuiushchih zenshchiny). [Extended abstract of candidate's thesis]. Cheliabinsk.

Dictionary of Ukrainian language (1970). (Vols. 11). Kyiv: Naukova dumka.

Evans, V., and Green, M. (2006). Cognitive linguistics: an introduction. Edinburgh: Edinburgh University Press.

Jørgensen, M, and Phillips, L. (2004) Discourse Analysis as Theory and Method London: SAGE Publications.

Karasyk, V. \& Slyshkin, G. (2001). Linuacultural Concept as a Unit of Study. Methodological problems of modern linguistics, 75-79

Karasyk, V. (2002). Language Circle: Personality, Concept, Discourse. Volgograd : Peremena.

Karpenko, N. (2009). P. Zagrebelny's Linguistic Consciousness: Representation of the ConceptCharacter Woman. Psycholinguistics, 4, 150-156.

Karpenko, N. (2010). P. Zagrebelnyas an Elite Linguistic Personality. V.N. Karazin Kharkiv National University Herald, 910, pp. 468-471 .

Kiefer, M., \& Pulvermüller, F. (2012). Conceptual Representations in Mind and Brain: Theoretical developments, current evidence and future directions. Cortex. 2012. 3, 805825 .

Kononenko, A. (2013). The Encyclopedia of Slavic culture, writing and mythology. Kharkov: Folio.

Lakoff, G. (2014). Mapping the brain's metaphor circuitry: metaphorical thought in everyday reason. Frontiers in Human Neuroscience. https://www.frontiersin.org/articles/10.3389/fnhum.2014.00958/full.

Langacker, R. (2009). Grammar and Conceptualization. Berlin, New York: Mouton de Gruyter. 
Lysychenko, L. (2009). Lexico-semantic dimension of language picture of the world. Kharkiv: Osnova.

Osipov, B. (2003). Dictionary of a modern Russian city. Moscow: OOO «Russkie Slovari», OOO «Ast», OOO «Strel», OOO «Transit-kniga».

Shaparova, N. (2001). A short encyclopedia of of Slavic mithologyi. Moscow: Ast .

Stepanov, Y. (2004). Constants: Dictionary of Russian Culture. Moscow: Academic Project.

Sukalenko, T. (2010). Metaphoric expression of the concept woman in the Ukrainian language: Kyiv: Instytut Ukrayinskoyi movy.

Vasiuk, V. (2002). Concept «Woman» in Statics and Dynamics of English Phraseology. [Extended abstract of candidate's thesis]. Moscow.

Vovk, O (2006). The Encyclopedia of Signs and Symbols. Moscow: Veche .

Zagrebelny, P. (2002). Yuliia, or invitation to suicide. Folio.

Zagrebelny, P. (2004). Yevpraksiia. Kharkiv: Folio.

Zagrebelny, P. (2006). Roksolana. Kharkiv: Folio.

Zhabotynska, S. (2009). Concep /domain: matrix and net models. The culture of people of Brack Sea Coastal area. 2009.

Zhaivoronok, V. (2006). Signs of Ukrainian Linguaculture. Kyiv: Dovira 